\title{
Covid-19 e a imaginação político-viral
}

\author{
VITOR GRUNVALD \\ Universidade Federal do Rio Grande do Sul, Porto Alegre, RS, Brasil \\ vgrunvald@gmail.com
}

DOI 10.11606/issn.2316-9133.v29i2pe170450

\begin{abstract}
Tomara que se propague um vírus ideológico diferente e muito mais benéfico, e só temos a torcer para que ele nos infecte: um vírus que faça imaginar uma sociedade alternativa, uma sociedade que vá além do Estado-nação e se realize na forma da solidariedade global e da cooperação.
\end{abstract}

(Slavoj Žižek, Virus)

O objetivo desse texto é tecer algumas relações que explicitam a construção de uma imaginação política em torno da pandemia deslanchada pelo novo coronavírus, mas que não se limita a ele, projetando-se em direção a outros imaginários no que tenho chamado de imaginação político-viral. Para início de conversa, portanto, é importante marcar que imaginação, aqui, não é tomada algo ilusório, mas sim como uma forma de consciência que aponta para caminhos reflexivos do próprio sujeito social (BUTLER 1987).

Em livro de diálogo entre Judith Butler, Slavoj Žižek e Ernesto Laclau, este último argumenta: "Eu vejo como uma das principais tarefas da teoria política, desenvolver os jogos de linguagem [para além da lógica hegemônica] e, assim, expandir a imaginação política” (LACLAU 2000: p.212). Marcadamente em tempos de crise, contudo, essa tarefa não é apenas levada a cabo por pensadoras e acadêmicas preocupadas em pensar a vida social e as dinâmicas políticas, mas, igualmente, pela sociedade civil de uma maneira ampla. ${ }^{1}$

As autoras do livro acima aludido todas, de alguma maneira, se viram implicadas na tarefa não apenas de expandir, mas de explicitar, analisar e problematizar a imaginação política ocidental em suas múltiplas configurações e atravessamentos. Foi o filósofo esloveno imbricado na discussão que, ao visitar, no dia 8 de outubro de 2011, a histórica manifestação Occupy Wall Street, afirmou: "É fácil para nós imaginar o fim do mundo - vejam os vários filmes apocalípticos! - mas não o fim do capitalismo". ${ }^{2}$

\footnotetext{
${ }^{1}$ Para uma discussão antropológica sobre a noção de sociedade civil, cf. Comaroff e Comaroff (1999).

${ }^{2}$ Para algumas questões adicionais sobre essa discussão, cf. Grunvald, 2019.
} 
Com a crise instaurada pela covid-19, parece que a linha que separa realidade e ficção já não oferece qualquer segurança, sendo, diversamente, alvo constante de investidas que buscam desafiar qualquer sensação de estabilidade: ontológica, político-social, sanitária.

Adicionalmente, para assentar as bases iniciais das reflexões que gostaria aqui de propor, lembremos que a crise mundial deslanchada pelo novo coronavírus tem sido, apara além de pandemia, também caracterizada como uma infodemia, "uma super abundância de informação - algumas corretas, outras não - que torna difícil para as pessoas encontrar fontes seguras e confiáveis de orientação quando precisam”3. Além da crise sanitária, portanto, há também, segundo a própria Organização Mundial de Saúde, uma crise em termos de quais informações e elementos são utilizados na construção de mapas mentais de orientação prática e política sobre o vírus que se alastrou desde Wuhan na China.

Origens são, obviamente, muito mais do que localizações geográficas. Os imbróglios políticos sobre como, de fato, pode ter surgido a atual crise sanitária se alimentam de uma série de elementos pré-existentes no imaginário político e social que, como bem lembrou Žižek, é abundantemente alimentado pelas mídias - aí, incluído, claro, o cinema - bem, como pelas redes sociais e aplicativos de compartilhamento de mensagens.

Desse conjunto totalmente heterogêneo de frases de efeito e memes compartilhados ad nauseum, surgem narrativas que ora enfatizam ora negam teorias bioquímicas da conspiração com acusações mútuas ${ }^{4} \mathrm{e}$, via de regra - como não haveria de ser diferente e se me permitem o trocadilho - possuem tons racistas bastante demarcados. Lembremos como, no dia 06 de abril de 2020, a Embaixada da China no Brasil se pronunciou criticamente contra o tom explicitamente racista de uma publicação feita pelo então ministro da Educação Abraham Weintraub.

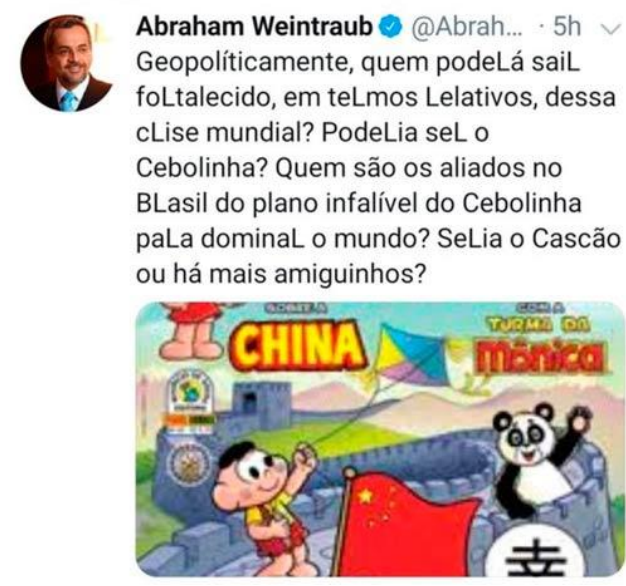

Figura 1. Publicação do então ministro da educação, Abraham Weintraub. Fonte: Twitter (2020).

\footnotetext{
${ }^{3}$ Tradução minha Ver o relatório da Organização mundial da saúde (aqui).

${ }^{4}$ Cf. por exemplo, a matéria de Christina Zhao para o Jornal News Week, em 26 de fevereiro de 2020 e a matéria publicada em 17 de março de 2020 na Folha de São Paulo..

Para percepções do tipo no Brasil, ver coluna de Tales Farias para o Uol.
} 
Justamente por serem eficientes na disseminação de elementos simbólicos operacionalizáveis para a construção de imaginário político é que as mídias e redes sociais têm sido tão inegavelmente mobilizadas como tecnologias de governo (ROSE 1999) apropriadas à disputa pelas representações e justificações de atos perpetrados por governos como o brasileiro e estadunidense. ${ }^{5}$

Butler inicia seu recente texto, O capitalismo tem seus limites, afirmando que:

O imperativo de isolamento coincide com um novo reconhecimento de nossa interdependência global no novo tempo e espaço da pandemia. Por um lado, somos solicitados a nos recolhermos em unidades familiares, espaços compartilhados de moradia, ou domicílios individuais, privados de contato social e relegados a esferas de relativo isolamento. Por outro lado, estamos diante de um vírus que transpõe tranquilamente as fronteiras, completamente alheio à própria ideia de território nacional. (BUTLER 2020: s/p)

Ao lado de um suposto "novo reconhecimento de nossa interdependência global" $\mathrm{e}$ do vírus ideológico que Žižek apresenta na epígrafe deste texto, portanto, aparece também a figura utópica de um organismo transnacional alheio às fronteiras estatais. Mas, ao largo de qualquer possibilidade de abolição da realidade territorial dos estados modernos, um cruzeiro que havia saído da Austrália no dia 28 de fevereiro estava ainda, em 16 de março, navegando sem rumo no Pacífico porque havia recebido recusa para aportar em quatro países, dentre eles o próprio território de origem. ${ }^{7}$

Nesse momento, recebia pelo Whats App um vídeo espanhol no qual um apresentador elucubrava sobre uma possível inversão das polaridades e fluxos migratórios: a Europa, infectada pelo novo coronavírus, havia se tornado porto de saída de imigrantes dessa vez, europeus e brancos - que tentavam fugir para a África que, em resposta, fechava suas fronteiras. Também eram publicadas, dessa vez a partir de notas oficiais, notícias sobre declarações de países como México, Estados Unidos e Canadá anunciando o fechamento das fronteiras para conter a pandemia. ${ }^{8}$

Para além do vírus transnacional, portanto, as fronteiras dos Estados-Nação, ao que parecem, são sempre possibilidades estrategicamente acionadas, antes que realidades defasadas, mesmo se consideramos o contexto pandêmico especificamente.

Em flagrante indicação da potência política da imaginação viral, o novo coronavírus foi também concebido como um comunavírus por Žižek no já citado livro Virus, publicado na Itália. Sua ideia central é que a pandemia mundial deixou latente os problemas e

\footnotetext{
${ }^{5}$ Para algumas reflexões sobre popularismo de direita e mídias digitais, cf. Cesarino (2019).

${ }^{6} \mathrm{Cf}$. também o texto de Egdar Morin disponível no portal Clima Terra.

${ }^{7}$ Cf. Rafael Veleda no Portal Metrópoles (26/03/2020).

${ }^{8}$ Para mais, ver a matéria publicada pelo portal G1, em 16/03/2020 (aqui). e a matéria conjunta entre o Jornal Extra e a Agência Reuters, em 13/03/2020 (aqui).
} 
insuficiências do capitalismo e seu foco exclusivo no lucro, afirmando, assim mesmo, a importância e necessidade de medidas que, há muito, são associadas à certa imagem política referida ao comunismo, como acesso universal à saúde e renda básica de apoio à população mais pobre e precarizada.

De fato, essas duas preocupações econômico-sanitárias foram centrais na constituição de políticas públicas de enfrentamento à pandemia em quase todos os países na qual ela se instalou. Em países europeus como Itália, França e Espanha, não apenas hospitais e serviços de saúde, mas companhias áreas e do setor automobilístico passaram a estatizar empresas contra os perigos tanto do vírus que se espalha por gotículas que voam no ar quanto da falência e decadência econômica. ${ }^{9}$

Em terras brasilianas, a leitura da obra de Žižek inspirou uma publicação do chanceler brasileiro, Ernesto Araújo, que, em seu blog, utiliza as palavras do autor para afirmar o perigo do que argumenta ser um novo momento do comunismo. O texto revela que o filósofo nem mesmo tenta disfarçar o caráter "ideológico" da crise, o que, certamente, como tudo que passa a ser acusado de ideologia no Brasil dos dias de hoje, possui valor iminentemente negativo.

Em suma, Žižek explicita aquilo que vinha sendo preparado há trinta anos, desde a queda do muro de Berlim, quando o comunismo não desapareceu, mas apenas dotou-se de novos instrumentos: o globalismo é o novo caminho do comunismo. O vírus aparece, de fato, como imensa oportunidade para acelerar o projeto globalista. Este já se vinha executando por meio do climatismo ou alarmismo climático, da ideologia de gênero, do dogmatismo politicamente correto, do imigracionismo, do racialismo ou reorganização da sociedade pelo princípio da raça, do antinacionalismo, do cientificismo. São instrumentos eficientes, mas a pandemia, colocando indivíduos e sociedades diante do pânico da morte iminente, representa a exponencialização de todos eles. (ARAÚJO 2020: $\mathrm{s} / \mathrm{p})$.

O ministro das Relações Exteriores, portanto, é astuto em comprimir politicamente muitos elementos num mesmo saco ideológico, ainda que o negue. Questões ambientais, de gênero, raça, classe, nação/imigração e ciência estariam, todas elas, inadvertidamente ligadas umas às outras nesse "projeto" que denomina globalismo, "uma ordem mundial sem nações". ${ }^{10}$

\footnotetext{
${ }^{9}$ Consultar matéria da revista Exame (17/03/2020 - disponível aqui), do portal de notícias G1, em 17/03/2020 (aqui), Jornal o Globo (em 17/03/2020 - aqui) e a edição de 1903/2020 do jornal Estado de São Paulo (disponível aqui).

${ }^{10}$ Em comentário incitado por um jornal brasileiro, Zizek responde: "O chanceler brasileiro me acusou de usar a epidemia do coronavírus como uma desculpa para introduzir outro vírus, o 'comunavírus'. Infelizmente, ele não entendeu a questão". (Disponível na íntegra aqui)
} 
Ainda que por caminhos diversos, Jim Robbins, jornalista do New York Times especialista em meio ambiente, e Bruno Latour, ubíquo pensador contemporâneo, mesmo que não enfatizem a ideia de projeto, encontram-se na percepção de que a atual crise sanitária, como outras epidemias, não simplesmente acontece, mas é fruto de escolhas e éticas ambientais mais amplas. ${ }^{11}$

O acadêmico francês, contudo, é mais enfático ao afirmar que, como ensaio geral para uma crise ambiental mais séria e abrangente, a pandemia da covid-19 ameaça a percepção difusa de que a sociedade que vivemos é determinada por "humanos entre si" e não por uma infinidade de actantes humanos e não-humanos em constante interação (LATOUR 2020)

E, novamente, ao pensar as consequências ecológicas do novo coronavirus, sou levado às imagens e notícias que recebo via redes sociais e aplicativos. Por exemplo, aquelas que mostram uma Veneza sem turistas e com poucos humanos, mas águas cristalinas navegadas não por gôndolas, mas cines e golfinhos. ${ }^{12} \mathrm{Ou}$ ainda notícias sobre a drástica redução da poluição do ar na China devido às restrições relativas ao confinamento impostas pelo governo. $^{13}$

Diante disso, ainda que possamos aproximar a atual crise sanitária e a crise ecológica, por outro lado, como o próprio Latour argumenta e os exemplos acima deixam claro:

[N]a crise da saúde, pode ser verdade que os seres humanos como um todo estão "lutando" contra vírus - mesmo que eles não tenham interesse em nós e sigam seu caminho de garganta em garganta nos matando sem nem mesmo querer. A situação é tragicamente revertida na mudança ecológica: desta vez, o patógeno cuja terrível virulência mudou as condições de vida de todos os habitantes do planeta não é o vírus, é a humanidade! (LATOUR 2020: s/p).

Sob esse prisma, as lições da covid-19 já não parecem apontar para um futuro tão comunitário no qual se reconhece a interdependência de todas com todas e de todas com o meio ambiente. Tampouco transparece imagem ou promessa mais positiva do empreendimento humanista e seus valores correspondentes.

Ao analisar o cenário, o sociólogo Alain Touraine (2020) adverte que "com essas crises há possibilidades de que um choque econômico produza reações que chamo de tipo fascista”. Algo que, obviamente, só o futuro dirá. Quanto à abertura de possibilidades para setores conservadores da sociedade, o que já se pode, inadvertidamente, observar é a manipulação da crise sanitária para abafar e "passar" mudanças que revertem direitos sociais

\footnotetext{
${ }^{11}$ Cf. o artigo "The ecology od disease", de Jean Robins, publicado na edição de 14/07/2012 do The New York Times (disponível aqui).

${ }^{12}$ Cf. Anagha Srikanth para o jornal The Hill (18/03/2020).

${ }^{13}$ Justine Calma em matéria publicada em 2/03/2020 no portal The Verge.
} 
e políticos de proteção ambiental, como tão bem deixou claro a fala do ministro brasileiro do Meio Ambiente Ricardo Salles em vergonhoso vídeo de uma reunião ministerial divulgado recentemente por ordem do Supremo Tribunal Federal. ${ }^{14}$

Touraine, como Latour, também critica a noção de "guerra contra o vírus", tão amplamente mobilizada pelos presidentes estadunidense Donald Trump e francês Emmanuel Macron. Na entrevista acima citada, o escritor bem pondera que, no caso do enfretamento à epidemia de covid-19, "[n]ão há estrategista: o vírus não é um chefe de Governo" (TOURRAINE 2020).

$\mathrm{O}$ vírus, biologicamente, não é humano. Mas, sendo um fenômeno social de interação entre humanos e não-humanos, a pandemia o é. E é por isso que "toda pandemia tem raça, gênero e classe”, como tão precisamente afirma Denise Pimenta ${ }^{15}$. São trabalhadoras informais, profissionais precarizadas e desempregadas aquelas que mais sofrem com as imposições de sua condição laboral ${ }^{16}$.

No momento em que se preconiza uma abertura gradual do comércio e retomada das atividades sem abertura das escolas, são mulheres as que mais sofrem, pois é sobre elas que recai, em geral, o cuidado com os filhos e filhas. Assim como, é na periferia, em geral negra, dos grandes centros urbanos, que o acesso ao sistema de saúde é mais difícil e insuficiente em relação ao nível de ocupação de leitos e necessidade de equipamentos, seja de EPIs para profissionais de saúde seja de respiradores para a população.

$O$ vírus, certamente, não é um chefe de governo, ainda assim, são governos e suas (necro)políticas que detém prerrogativas importantes de administração da crise sanitária instalada pelo novo coronavírus. E é por isso que, do ponto de vista explorado aqui, a noção de uma guerra contra o vírus parece algo justificável, pois a reestruturação da imaginação política e dos sentidos sociais a partir dos quais lemos os processos e o mundo que nos cerca - objeto que este texto buscou parcialmente explicitar - só é possível em momentos de crise, seja política, como as guerras, ou sanitária, como as epidemias. Afinal, como costumam dizer ao parafrasear Darwin, a história, assim como a natureza, não dá saltos.

\section{Referências Bibliográficas}

ARAÚJO, Ernesto. (2020). Chegou o comunivírus. Blog Metoapolítica 17, publicação de 22 de abril de 2020. Disponível em: https://www.metapoliticabrasil.com/post/chegou-ocomunav\%C3\%ADrus acesso em 17/12/2020

CESARINO, Letícia. (2019). Identidade e representação no bolsonarismo: corpo digital do rei, bivalência conservadorismo-neoliberalismo e pessoa fractal. Revista de Antropologia, v.62, n.3, p.530-557.

\footnotetext{
${ }^{14}$ Cf. matéria de Matheus Lara e Matheus Piovesana para o Agência Estadão em 23/05/2020.

${ }^{15}$ Em entrevista para o portal Globo News (disponível aqui).

${ }^{16} \mathrm{Cf}$. a esse respeito, o Manifesto das filhas e dos filhos de empregadas(os) domésticas(os) e diaristas, disponível no portal do Mídia Ninja.
} 
COMAROFF, John; COMAROFF, Jean. (1987). Civil Society and the Political Imagination in Africa: Critical Perspectives. Chicago: University of Chicago Press, 1999.

BUTLER, Judith. (1987). Subjects of desire. Hegelian reflections in Twentieth-Century France. New York: Columbia University Press.

BUTLER, Judith. (2020). O capitalism tem seus limites. Blog da Boitempo, 20/03/2020. Disponível em https://blogdaboitempo.com.br/2020/03/20/judith-butler-sobre-ocovid-19-o-capitalismo-tem-seus-limites/

BUTLER, Judith; ŽIŽEK, Slavoj; LACLAU, Ernesto. (2000). Contingency, Hegemony, Universality. Contemporary dialogues on the Left. London, New York: Verso.

GRUNVALD, Vitor. (2019). Sugestões especulativas de Boca de lixo ou As vicissitudes do fim do mundo e do fazer fílmico documental. In: LIMA, Maria Raquel de Passos; GRUNVALD, Vitor; JESSOUROUN, Theresa. Boca de lixo visto por. Rio de Janeiro: 7 Letras.

LATOUR, Bruno Latour. (2020). Isto é um ensaio geral? Publicado em Antropológicas Epidêmicas (28/07/2020). Disponível em https://www.antropologicasepidemicas.com.br/post/isto-\%C3\%A9-um-ensaio-geral acesso em 17/12/2020

ROSE, Nikolas. (1999). Powers of freedom: reframing political thought. Cambridge: Cambridge University Press.

TOURRAINE, Allan. (2020). Entrevista a Marc Bassed. Jornal El País, 31/03/2020. Disponível em https://brasil.elpais.com/ideas/2020-03-31/alain-touraine-choqueeconomico-do-coronavirus-pode-produzir-reacoesfascistas.html?utm_source=meio\&utm_medium

\section{Sobre o autor}

\section{Vitor Grunvald}

É antropólogo e realizador audiovisual. Professor da UFRGS, onde coordena o Núcleo de Antropologia Visual (Navisual). Possui doutorado em doutor em Antropologia pela USP.

Recebido em 29/06/2020

Aceito para publicação em 17/12/2020 